Jurnal Care Vol .6, No.1,Tahun 2018

\title{
Metode Glenn Doman Meningkatkan Kemampuan Interaksi Sosial Anak Autis
}

\author{
Desy Aydillah, Rokhaidah \\ Program Studi Ners Fikes UPN Veteran Jakarta \\ e-mail: rokhaidah@yahoo.com
}

\begin{abstract}
Autism is a complex developmental disorder typically arising during the first three years of life, with one of its characteristics being a disorder of social interaction. Children with autism have difficulty social relationships with others around them, tend to occupy themselves with self-involved activities, and generally with inanimate objects. This study aims to determine the effectiveness of Glenn Doman's method of social interaction ability of autistic children. This research is a quasi experimental research with one group pretest posttest design approach. The sample used were 15 autistic children with autistic children inclusion criteria that did not experience visual and hearing impairment. Sampling technique with total sampling. Final evaluation for social interaction variables using the ATIS (Autism Treatment Evaluation Checkliest) observation sheet. The results showed that Glenn Doman method can improve the social interaction ability of autistic children. Researchers recommend to families with children with autism, to apply Glenn Doman Method as an exercise to be able to improve the social interaction ability of children with autism.
\end{abstract}

Keywords: Glenn Doman Method;Autistic Child;Social Interaction

\begin{abstract}
ABSTRAK
Autis adalah gangguan perkembangan kompleks secara khas yang muncul selama tiga tahun pertama kehidupan, dengan salah satu karakteristiknya adalah gangguan interaksi sosial. Anak autis sulit melakukan hubungan sosial dengan orang lain di sekitar mereka, cenderung menyibukkan diri dengan aktifitas yang melibatkan diri sendiri, dan pada umumnya dengan benda-benda mati.Penelitian ini bertujuan untuk mengetahui efektifitas metode Glenn Doman terhadap kemampuan interaksi sosial anak autis. Penelitian ini merupakan penelitian quasi eksperimental dengan design pendekatan one group pretest posttest design. Sampel yang digunakan sebanyak 15 anak autis dengan kriteria inlusi anak autis yang tidak mengalami gangguan penglihatan dan pendengaran. Teknik pengambilan sample dengan total sampling. Evaluasi akhir untuk variabel interaksi sosial dengan menggunakan lembar observasi ATEC (Autisme Treatment Evaluation Checkliest).Hasil penelitian menunjukkan bahwa metode Glenn Doman dapat meningkatkan kemampuan interaksi sosial anak autis. Peneliti merekomendasikan kepada keluarga dengan anak autis, untuk mengaplikasikan Metode Glenn Doman sebagai latihan untuk dapat meningkatkan kemampuan interaksi sosial anak autis.
\end{abstract}

Kata Kunci : Metode Glenn Doman;Anak Autis;Interaksi Sosial 
Jurnal Care Vol .6, No.1,Tahun 2018

\section{PENDAHULUAN}

Autis merupakan suatu kumpulan sindrom yang mengganggu saraf, diagnosisnya diketahui dari gejala-gejala yang tampak dan ditunjukkan dengan adanya penyimpangan perkembangan (Rahmawati, 2012). Jumlah kasus autisme mengalami peningkatan yang cukup signifikan dari tahun ke tahun. Menurut penelitian selama 50 tahun terakhir tercatat prevalensi autis mengalami peningkatan di seluruh dunia. Direktur Bina Kesehatan Jiwa Kementerian Kesehatan menyatakan bila diasumsikan dengan prevalensi autisme 1,68 per 1.000 untuk anak di bawah 15 tahun dimana jumlah anak usia 5-19 tahun di Indonesia mencapai 66.000.805 jiwa (BPS, 2010).

WHO (2013) epidemiologi data global memperkirakan prevalensi autisme mencapai 1:160 atau 7,6 juta pertahun. Autisme menduduki 0,3\% dari beban penyakit global. Setiap tahun nya terdapat peningkatan jumlah anak autis pada rentang usia 5-19 tahun. Anak autis memiliki masalah yang sangat mempengaruhi perkembangan baik mental maupun fisik anak. Apabila tidak di lakukan penanganan dini dan tata laksana yang tepat, sulit di harapkan perkembangan yang optimal akan terjadi pada anak-anak tersebut. Adanya ganggun komunikasi, interaksi dan perilaku tersebut, semakin mengganggu dan semakin banyak dampak negatif yang akan terjadi pada anak. Anak akan terasing dari pergaulan di lingkungannya (Mahardani, 2016)

Anak autis memiliki beberapa hambatan yang dialami sehingga berdasarkan karakteristik tersebut mengakibatkan anak autis sulit melakukan hubungan sosial dengan orang lain di sekitar mereka. Anak autis tidak akan bergabung dalam aktivitas sosial dan memilih terpisah dari kelompok temannya atau ia tetap berada dalam kelompok tapi keberadaannya tidak terlihat dalam kelompok. Anak autis akan cenderung menyibukkan diri dengan aktifitas yang melibatkan diri sendiri, pada umumnya dengan bendabenda mati. Kesadaran sosial yang kurang menyebabkan anak autis tidak mampu untuk memahami ekpresi wajah orang, ataupun untuk mengekspresikan perasaannya sendiri (Mahardani,2016). Penelitian Must,dkk (2015) mengatakan bahwa gangguan sosial dan perilaku yang dialami anak-anak dengan autisme membuat partisipasi dalam bentuk aktivitas fisik terstruktur dan tidak terstruktur lebih sulit. 
Orangtua anak dengan autis telah melaporkan bahwa kemampuan motorik, kemampuan sosial, dan komunikasi anak mereka yang terbatas menjadikan hambatan anak untuk berpartisipasi kegiatan aktivitas fisik setelah sekolah (Obrusnikova \& Cavalier, 2011). Prevalensi hambatan interaksi sosial yang tinggi pada anak autis dilaporkan oleh orang tua, sebanyak $62 \%$ orang tua anakanak dengan autis melaporkan 2 atau lebih hambatan interaksi sosial yaitu kesulitan keterampilan sosial (77\%), diikuti oleh persepsi bahwa orang dewasa yang mengawasi kegiatan anak autis tidak memiliki keterampilan yang memadai (59\%) (Phillips, Carol, \& Bandini, 2015).

Metode Glenn Doman merupakan salah satu terapi atau penatalaksanaan pada anak autis yang mengalami gangguan interaksi sosial. Metode glenn doman merupakan salah satu metode belajar membaca pada balita, dan saat ini metode glenn doman sangat digemari oleh masyarakat kita dalam mengajarkan putra-putri mereka membaca diusia yang sangat dini, dengan cara stimulasi metode glenn doman yang menggunakan kartu bergambar serta menyertakan tulisan akan membantu memberikan stimulasi anak dalam responnya berbicara, berkomunikasi dan penguasaan bahasa.
Selain membuat potensi kecerdasan anak tergali dengan maksimal, mendidik anak dengan metode glenn doman ini pun dapat mempererat hubungan antara orangtua dan anak apabila orang tua mampu memberikan metode glenn doman ini terhadap anaknya. Tujuan utama yang diharapkan melalui metode glenn doman adalah menumbuhkan rasa confident (percaya diri), imaginative (berimajinasi), dan happy (ceria)pada anak (Ahmadi, 2010).Berdasarkan latar belakang tersebut maka tujuan penelitian ini adalah untuk menganalisis pengaruh metode glenn doman terhadap kemampuan interaksi sosial anak autis.

\section{METODE PENELITIAN}

Metode penelitian yang digunakan adalah quasi eksperimental dengan rancangan penelitian one group pretest and postest design.Subyek dalam penelitian ini adalah anak autis, dengan kriteria inklusi adalah anak autis yang tidak mengalami gangguan penglihatan dan pendengaran. Teknik pengambilan sampel adalah total sampling sebanyak 15 anak.

Intervensi Metode Glenn Doman dilakukan dalam 4 tahap, dengan frekuensi pertemuan 14 kali selama 7 hari. Tahap metode glenn doman dalam penelitian ini adalah sebagai berikut: 
1. Tahap Pertama: a) Hari pertama (pagi), pengenalan 8 kata sederhana, yaitu nama-nama buah: pisang, nanas, anggur, manggis, jeruk, apel, stawbery dan pepaya. Tidak perlu menjelaskan apa-apa. b) Hari pertama (siang), pengulangan 8 kata di pagi hari. Kemudian akan ditambah 8 kata yang baru, yaitu nama-nama binatang: monyet, kucing, katak, kelinci, kuda, kupu-kupu, gajah dan tikus. c) Hari kedua (pagi dan siang) mengulang 24 kata seperti hari pertama, tidak ada penambahan kata-kata baru. d) Hari kedua (Evaluasi), beri kesempatan pada anak untuk memperlihatkan kemajuannya: Pilih kata kesukaannya, Pilih 2 kartu yang sudah pernah dimainkan. Misalnya kartu "apel” dan "pepaya”. Pegang kedua kartu tersebut di tangan kanan dan kiri anda, kemudian tunjukkan halaman tulisan kata "apel" dan "pepaya" didepan anak anda. Mintalah anak mengambil salah satu nama kartu, misalnya, Ibu mengatakan, "yang mana apel ?”. Jika anak tersebut menunjukkan kata yang benar, pastikan ikut gembira dan tunjukkan kegembiraan, dan jika anak tidak memberikan jawaban atau salah, tunjukkan kata yang benar dan teruskan pelajarannya.
2. Tahap Kedua

Pada tahap ini anak akan mulai diajarkan membaca dengan menggunakan nama-nama anggota tubuh karena anak memang mula-mula mempelajari badannya sendiri, selain itu mengenalkan nama-nama bentuk dan berbagai macam warna. a) Hari ketiga (pagi), pengenalan 8 kata namanama anggota tubuh. Misalnya: kaki, tangan, mata, hidung, telinga, gigi, bibir, dan rambut. Tidak perlu menjelaskan apa-apa. b) Hari ketiga (siang), pengulangan 8 kata di pagi hari. Kemudian akan ditambah 8 kata yang baru, yaitu nama-nama bentuk seperti persegi, lingkaran, segitiga, garis, kubus, setengah lingkaran, persegi panjang, dan tanda silang. c) Hari Keempat (pagi, siang, dan sore), mengulang 24 kata seperti hari ketiga, tidak ada penambahan kata-kata baru. d) Hari Keempat, lakukan evaluasi seperti pada tahap pertama.

\section{Tahap Ketiga}

a) Hari kelima (pagi), mengenalkan 8 kata yang terdiri dari nama-nama benda di sekeliling anak serta lebih dari 2 suku kata, misalnya: kursi, meja, jaket, bola, pintu, sendok, sepatu, dan baju. b) Hari kelima (siang), mengulang 8 kata di pagi hari. Kemudian menambahkan 8 lawan kata, misalnya: 
besar, kecil, di depan, di belakang, di bawah, di atas, panas, dingin, pria dan wanita. c) Hari kelima (siang) mengulang 8 kata di pagi hari dan 8 kata di siang hari. Setelah itu masukkan 8 kata perbuatan atau aktivitas, misalnya: melompat, makan, minum, tidur, berdiri, menangkap bola, memakai baju atau mengancing baju, dan mandi. Pada tahap kata perbuatan, agar lebih menarik, sambil menunjukkan kata tersebut, anda praktekkan sambil katakan "Ibu melompat", "kakak melompat". d) Hari keenam (pagi dan siang). Mengulang 24 kata yang sudah diajarkan pada hari kelima. e) Hari keenam. Setelah 24 kata tersebut sudah diajarkan kemudian lakukan evaluasi seperti pada tahap pertama.

4. Tahap Keempat

a) Tunjukkan kata demi kata seperti tahap sebelumnya lalu gabungkan misalnya: Tunjukkan kartu “monyet”, "makan”, "pisang", “apel”, dengan menggunakan alur cerita, "Monyet makan pisang dan apel". b) Kumpulan kata-kata yang pernah dibaca, dikumpulkan kembali, lalu meminta anak untuk menyusun sendiri kalimat mereka.
Evaluasi akhir untuk variabel interaksi sosial dengan menggunakan lembar observasi ATEC (Autisme Treatment Evaluation (heckliest). ATEC terdiri dari 4 subtes, yaitu: (1) Bicara atau komunikasi bahasa 14 item, (2) Sosialisasi 20 item, (3) Sensori atau kesadaran kognitif 18 item, (4) Kesehatan/fisik/perilaku 25 item (Rimlan and Edelson, 2016). Jadi secara keseluruhan ATEC memiliki 77 item atau pernyataan yang harus direspon.

Setiap item yang telah direspon akan di konversi menjadi angka atau skor dengan prosedur sebagai berikut:

$0=$ Responden memilih respon "Tidak Benar", “Tidak Pernah Terlihat", dan "Bukan Masalah" pada pernyataan yang ada.

$1=$ Responden memilih respon "Agak Benar, "Kadang Terlihat" dan "Masalah Kecil" pada pernyataan yang ada.

$2=$ Responden meilih respon "Sangat Benar", "Sangat Terlihat" dan "Cukup Bermasalah" pada pernyataan yang ada.

3= Responden memilih respon "Sangat Bermasalah" pada pernyataan yang ada. 


\section{HASIL}

Karakteristik Usia dan Jenis Kelamin

Tabel 1 Distribusi Frekuensi Usia Responden Anak Autis

\begin{tabular}{ccc}
\hline Variabel & Mean & Min-Max \\
\hline Usia & 12,93 & $6-22$ \\
\hline
\end{tabular}

Tabel 2 Distribusi Frekuensi Jenis Kelamin Responden Anak Autis

\begin{tabular}{lcc}
\hline \multicolumn{1}{c}{ Variabel } & Jumlah & $\mathbf{0}$ \\
\hline Jenis Kelamin & & \\
Laki-laki & 11 & 26,7 \\
Perempuan & 4 & 73,3 \\
\hline \multicolumn{1}{c}{ TOTAL } & $\mathbf{1 5}$ & $\mathbf{1 0 0}$ \\
\hline
\end{tabular}

\section{Interaksi Sosial Anak Autis Sebelum dan Sesudah Intervensi}

Tabel 3 Skor Interaksi Sosial Anak Autis Sebelum (Pretest) dan Sesudah (Posttest)

\begin{tabular}{lllllll}
\hline \multirow{2}{*}{ Interaksi Sosial } & \multicolumn{4}{c}{ Pretest } & \multicolumn{2}{c}{ Posttest } \\
\cline { 2 - 7 } & Mean & SD & Min -Max & Mean & SD & Min -Max \\
\hline Sosialiasi &, 53 & 4,658 & $1-18$ & 3,53 & 6,968 & $14-38$ \\
\hline Komunikasi &, 80 & 3,189 & $1-10$ & 9.13 & 4,015 & $15-28$ \\
\hline Perilaku &, 80 & 4,127 & $3-14$ & 2,80 & 3,858 & $18-31$ \\
\hline Kesehatan & 0,00 & 5,057 & $12-27$ & 0,27 & 5,298 & $12-27$ \\
\hline Total Skor ATEC & 9,07 & 15,346 & $20-69$ & 5,73 & 10,532 & $70-109$ \\
\hline
\end{tabular}

Tabel 4 Analisis Perbedaan Pengaruh Metode Glenn Doman Terhadap Interaksi Sosial Anak Autis Pretest dan Postest ( $\mathrm{n}=15)$

\begin{tabular}{cccc}
\hline Interaksi Sosial & Mean & SD & P Value \\
\hline Pretest & 9,07 & 15,346 & \multirow{2}{*}{0,000} \\
Posttest & 5,73 & 10,532 & \\
\hline
\end{tabular}

Hasil analisis dari 15 responden anak autis didapatkan hasil rata-rata skor interaksi sosial pada pengukuran pertama (Pretest) adalah 39,07 dengan skor standar deviasi 15,346. Pada pengukuran ke dua (Posttest) didapatkan rata-rata skor interaksi sosial adalah 85,73 dengan skor standar deviasi 10,532. Terlihat nilai mean perbedaan antara pengukuran pertama (Pretest) dan kedua (Posttest) adalah 46,66 dengan standar deviasi 4,814. Hasil uji statistik didapatkan $P_{\text {value }} 0,000$ maka dapat disimpulkan ada perbedaan yang signifikan antara skor interaksi sosial anak autis di SKh As-Salam 02 Serpong Tangeranga Selatan Tahun 2017 pengukuran pertama (Pretest) dan kedua (Posttest). 
Jurnal Care Vol .6, No.1,Tahun 2018

\section{PEMBAHASAN}

Rata-rata interaksi sosial anak autis sesudah (postest) diberikan intervensi didapatkan hasil rata-rata skor item komunikasi posttest adalah 19,13 $\pm 4,015$ dengan skor terendah 15 dan skor tertinggi 28 (68,32\%); Rata-rata skor item Sosialisasi posttest adalah 23,53 $\pm 6,968$ dengan skor terendah 14 dan skor tertinggi 38 (58,83\%); Rata-rata skor item

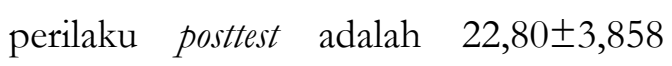
dengan skor terendah adalah 18 dan skor tertinggi 31 (63,33\%); Rata-rata skor item kesehatan posttest adalah 20,27士5,298 dengan skor terendah adalah 12 dan skor tertinggi 27 (27,02\%); Total skor posttest adalah $85,73 \pm 10,532$ rata-rata skor tersebut mengalami peningkatan sebesar 46,66 dengan skor terendah 70 dan skor tertinggi adalah 109 (47,62\%), dimana skor sebelum terendah sebelumnya 20 dan skor tertinggi sebelumnya adalah 69. Data tersebut menunjukan adanya peningkatan hasil skor ATEC (Autism Treatment Evaluation (hecklist).

Kondisi anak autis saat intervensi meliputi hambatan dalam berbicara dan berbahasa, kemampuan berkomunikasi secara verbal maupun non verbal menjadi masalah utama dalam interaksi sosial anak autis. Intervensi metode Glenn Doman dilaksanakan di sekolah luar biasa (SLB), pada saat pelaksanaan intervensi terdapat beberapa anak yang acuh tak acuh dan asyik dengan dunianya sendiri, ada juga beberapa anak autis yang dapat mengikuti dengan baik proses penelitian. Interaksi sosial anak autis memiliki karakteristik yang unik, terdapat anak yang melakukan sesuatu berulang-ulang, membenturkan kepala dan berteriak.

Penelitian yang dilakukan oleh Kerti, dkk (2012) bahwa interaksi sosial anak autis yang berjumlah 40 anak hasil nya adalah interaksi sosial anak autis yang kategorinya kurang baik berjumlah 2 anak (5,0\%), kategori sedang berjumlah 31 anak $(77,5 \%)$, dan kategori baik berjumlah 7 anak (17,5\%). Dan penelitian yang dilakukan Rapmauly dan Martulesssy (2015) tentang pengaruh terapi bermian flashcard untuk meningkatkan interaksi sosial anak autis di Miracle Center Surabaya, hasil dari penelitian ini menunjukan bahwa dimensi kepatuhan kontak mata saat sebelum diberikan terapi flashcard memiliki rata-rata keseluruhan sebesar 0,333. Pada dimensi menirukan nilai ratarata keseluruhan sebesar 0,315. Dimensi bahasa reseptif nilai rata-rata keseluruhan sebesar 0,288. Dimensi bahasa ekpresif nilai rata-rata keseluruhan sebesar 0,250, 
Jurnal Care Vol .6, No.1,Tahun 2018

dimana rata-rata masih dalam skor minimum.

Data mengenai kemampuan interaksi sosial anak pada penelitian ini didapatkan hasil skor ATEC nya adalah 39.07, standar deviasi 15.346, dengan skor terendah 20 dan skor tertinggi adalah 69. Teori menyatakan bahwa semakin tinggi skor ATEC, maka semakin sedikit masalah. Karena fungsi utama ATEC (Autism Treatment Evaluation Checklist) adalah untuk mengukur efektifitas intervensi (Rusianto, 2016). Skor untuk item komunikasi (0-28), sosialisasi (0-40), perilaku (0-36), kesehatan (0-75).Total skor distibusi ATEC terendah adalah 0 dan tertinggi adalah 180 (Geier, et al 2013). Dapat disimpulkan skor ATEC anak autis dalam penelitian ini masih jauh dari skor tertinggi ATEC (Autism Treatment Evaluation Checklist) sebagai bahan standar nilai evaluasi intervensi.

Menurut Maulana (2010) minimal ada 2 gejala yang timbul dari gejala-gejala berikut pada anak yang mengalami gangguan interaksi sosial yaitu: a) tidak mampu menjalin interaksi sosial yang cukup memadai, kontak mata sangat kurang, ekspresi wajah yang kurang hidup, gerak-gerik yang kurang fokus. b) tidak bisa bermain dengan teman sebaya. c) tidak dapat merasakan apa yang dirasakan orang lain. c) Kurangnya hubungan sosial dan emosional yang timbal balik.

Penelitian yang dilakukan Rapmauly dan Martulesssy (2015) tentang pengaruh terapi bermain flashcard untuk meningkatkan interaksi sosial anak autis di Miracle Center Surabaya, hasil dari penelitian ini menunjukan bahwa dimensi kepatuhan kontak mata saat sebelum diberikan terapi flashcard memiliki rata-rata keseluruhan sebesar 0,333. Pada dimensi menirukan nilai ratarata keseluruhan sebesar 0,315. Dimensi bahasa reseptif nilai rata-rata keseluruhan sebesar 0,288. Dimensi bahasa ekpresif nilai rata-rata keseluruhan sebesar 0,250. Dimana rata-rata masih dalam skor minimum. Data mengenai kemampuan interaksi sosial anak pada penelitian ini didapatkan hasil skor ATEC nya adalah 39.07, standar deviasi 15.346, dengan skor terendah 20 dan skor tertinggi adalah 69. Teori menyatakan bahwa semakin tinggi skor ATEC, maka semakin sedikit masalah. Karena fungsi utama ATEC (Autism Treatment Evaluation Checklist) adalah untuk mengukur efektifitas intervensi (Rusianto, 2016). Skor untuk item komunikasi (0-28), sosialisasi (0-40), 
Perilaku (0-36), Kesehatan (0-75) Total skor distibusi ATEC terendah adalah 0 dan tertinggi adalah 180 (Geier, et al 2013). Dapat disimpulkan skor ATEC anak autis dalam penelitian ini masih jauh dari skor tertinggi ATEC (Autism Treatment Evaluation Checklist) sebagai bahan standar nilai evaluasi intervensi. Dari pengamatan peneliti anak autis lebih asik dengan dunianya sendiri dimana lebih suka menyendiri di kelas, kontak mata kurang, susah untuk menerima perintah dan hanya melakukan kegiatan yang dianggapnya menarik.

Metode glenn doman adalah metode pengajaran membaca pada anak dengan menggunakan flash card sehingga anak akan mempunyai rasa confident, imagenative, happiness. Glenn Doman adalah seorang pencipta ide dari kelompok yang tidak melihat faktor nature biologis. Dimana glenn doman menggunakan programflashcard dalam mengajari membaca untuk memberikan pendidikan pada anak. Glenn Doman memandang bagi otak tidak ada perbedaan apakah melihat atau mendengar sesuatu, tetapi otak dapat mengerti keduanya dengan baik. Bahkan yang dibutuhkan adalah suara yang cukup kuat dan cukup jelas untuk didengar telinga dan perkataan yang cukup besar dan cukup jelas untuk dilihat mata, sehingga otak dapat menafsirkan. Telinga dapat menerima rangsangan suara, baik sepatah kata atau pesan lisan, maka pesan pendengaran dapat diuraikan menjadi serangkaian impuls elektrokimia dan diteruskan ke otak yang dapat melihat untuk disusun dan diartikan menjadi katakata yang dapat difahami. Begitupun dengan mata melihat sebuah kata atau pesan tertulis. Pesan visual diuraikan menjadi satu susunan impuls elektrokimia dan diteruskan ke otak yang tidak dapat melihat untuk disusun kembali dan difahami. Pada jalur penglihatan maupun pendengaran sama-sama menuju ke otak, dimana kedua pesan ditafsirkan otak dengan proses yang sama (Ahmadi, 2010).

Glenn doman memberikan panduan napak tilas yaitu dari patterning (memanipulasi anggota badan dan kepala dalam gerak yang ritmit), merayap, merangkak, stimulasi reseptif yang merangsang visual, perabaan, dan pendengaran anak, kegiatan ekspresif, masking (bernapas ke dalam masker oksigen untuk meningkatkan banyaknya oksigen terhirup, yang dipercaya meningkatkan aliran darah di otak), berayun pada palang, dan kegiatan gravitasi. Intinya yaitu, pada prinsipnya metode yang diajarkan glenn doman adalah menstimulasi otak secara maksimal untuk membuat jembatan-jembatan baru 
menutupi bagian otak yang cedera (Aulia, 2011).

\section{KESIMPULAN}

Terdapat perbedaan yang signifikan antara skor interaksi sosial anak autis pada pengukuran pertama (Pretest) dan kedua (Posttest) $\left(\mathrm{P}_{\text {value }}=0,000\right)$ sehingga dapat disimpulkan bahwa Metode Glenn Doman berpengaruh terhadap interaksi sosial anak autis.

Saran bagi peneliti selanjutnya adalah dengan melibatkan kelompok kontrol sebagai pembanding untuk mencegah terjadinya bias. Perlu juga ditambahkan lebih banyak modifikasi lain seperti kegiatan outbond dalam penerapan metode Glenn Doman untuk menghindari ketidaknyamanan yang terjadi pada anak selama proses penelitian berlangsung. peneliti juga menyarankan dilakukan pengklasifikasian anak autis untuk membandingkan antara anak autis yang aloof, aktif dan pasif apakah ada perbedaan yang signifikan keberhasilan pemberian terapinya.

\section{UCAPAN TERIMAKASIH}

Terimakasih peneliti sampaikan kepada para reviewer yang telah memberikan masukan untuk kebaikan penelitian ini, terima kasih juga kepada institusi UPN
Veteran Jakarta atas semua dukungan sehingga penelitian ini dapat terlaksana.

\section{REFERENSI}

Ahmadi, F. (2010). Meningkatkan minat membaca siswa sekolah dasar dengan metode glenn doman berbasis multimedi. Jurnal Penelitian PendidikanVolume 27 Nomor 1 Tahun PGSD FIP UNNES

Badan Pusat Statistik.(2010). Data Statistik Indonesia. Jumlab Penduduk menurut Kelompok Umur, Jenis Kelamin, Provinsi, dan Kabupaten/Kota, 2005. Diakses pada tanggal 29 April 2015.

Dari http://demografi.bgs.go.id/.

Matulessy, A \& Rapmauly, D. (2015). Pengaruh Terapi Bermain Flashcard Untuk Meningkatkan Interaksi Sosial Pada Anak Autis di Miracle Centre Surabaya, Pesona Jurnal Psikologi Indonesia. Januari 2015 Vol. 4 No. 1 hal 51-60

Maulana, M. (2010). Mendidik Anak Autis dan Gangguan Mental Lain Menuju Anak Cerdas dan Sehat, Kata Hati, Yogyakarta.

Must, A. Phillips, MS. Carol. C. \& Bandini. LG. (2015). Barriers to physical activity in children with autism spectrum disorders: Relationship to physical activity and screen time. J Phys Act Health. April 2015 Vol 12(4). hal 529-534.

Obrusnikova, I, \& Cavalier AR. (2011). Perceived barriers and facilitators of participation in after-school physical activity by children with autism spectrum disorders. J Dev Phys Disabil. 2011;23:195-211. 
Jurnal Care Vol .6, No.1,Tahun 2018

Peters, T. (2010). Panduan Autisme Terlengkap: Hubungan Antara Pengetabuan teoritis dan Intervensi Penddikan Bagi Penyandang Autis. Dian Rakyat, Jakarta

Rahayu, F (2014). Kemampuan Komunikasi Anak Autis Dalam Interaksi Sosial (kasus Anak Autis di Sekolah Inklusi, SD Negeri Giwangan Kotamadya Yogyakarta. Skripsi Program Sarjana Pendidikan, Universitas Negeri Yogyakarta

Rahmawati, S (2012). Pengaruh Metode $A B A$ : kemampuan bersosialisasi terhadap kemampuan interaksi sosial anak autis di SLB Taman Pendidikan Asuban Kabupaten Jember, Skripsi Program Studi Ilmu Keperawatan, Universitas Jember

Ramadian, S. (2010), Interaksi Sosial Asosiasif dan disasosiasif, di akses tanggal 8 April 2017 jam 10:00, http://www.scrib.com/doc/43I2 2I67/interaksi-sosial-asosiasifdan-disasosiasif.html

Rienekasar \& Nenden, R. (2014). Pengaruh Metode Glenn doman Dalam Meningkatkan Kemampuan Menyimak dan Membaca Anak Usia Dini, Tesis Magister Pendidikan SPs, Universitas Pendidikan Indonesia

Rimland, B \& Edelson, S. (2016). The autism treatment evaluation checklist. http://www.autism.com/index.p $\mathrm{hp} / /$ indatecreport diakses pada tanggal 20 maret 2017 jam 10:00

World Health Organization. (2013). Autism Spectrum Disorder \& Other Development Disorder from Raising Awareness to Buildng Capacity, Meeting report 